\title{
The Growth of Privatization in Higher Education as a Global Trend in China
}

\author{
Huijuan Lin \\ Beijing Institute of Technology Zhuhai Campus \\ School of Accounting and Finance \\ Zhuhai, China \\ TARO_930@126.COM
}

\begin{abstract}
This As one of the largest developing countries in the world with its rapid growth rate in the economy, China has achieved remarkable increase in its private higher education sector. Thanks to the policies of marketization and diversification in higher education, private higher education has played a considerably important role in China which is comparable to the role public higher education has. Following a review of the literature, analysis and discussion will be carried out to demonstrate the driving forces of privatization of higher education in China under the particular social and economic context of marketization. After the analysis and discussion of the driving forces, some of the arising crucial issues during the process of the rapid expansion of China's private higher education will be illustrated. Finally, recommendations will be made on how to keep the development of private higher education on a healthy and sustainable track for the long-term.
\end{abstract}

Keywords—Privatization, Higher Education, Growth

\section{INTRODUCTION}

During the late 1980s to early 1990s, the world political structure significantly changed due to the fall of the Soviet Union and the intense political changes in some of the Eastern European countries. Due to such dramatic political changes, the economic system of these countries has changed from command-centralized planned economies to market-oriented economies. As a result, the impact of marketization has led to privatization of higher education worldwide in various forms at unprecedented growth rates. As one of the largest developing countries in the world with its rapid growth rate in the economy, China has achieved remarkable increase in its private higher education sector. Thanks to the policies of marketization and diversification in higher education, private higher education has played a considerably important role in China which is comparable to the role public higher education has.

Before the reform and 'opening-up' policies, the only source of funding for all higher education institutes (HEIs) in China was from the national government. However, after the reform of the economy, the Chinese government has decided to adopt more market-oriented policies for higher education so as to expedite the growth of the economy. The decision to reform the education system, made by the Central Committee of Chinese Communist Party (CCCCP, 1985), in 1985 marked the significant beginning of education system reform of China Local governments were authorized to have more autonomy regarding the management issues on $\mathrm{HE}$ management, and strict controls upon HEIs were reduced to provide more space for HEI development. Consequently, the education system has gradually adjusted to meet the demand of economic growth. It was pointed out by Chou (2008) that, in order to diversify the educational system in China, non-public economic entities were allowed and encouraged to get involved in the operation of educational institutes, and more flexible policies were introduced to provide more autonomy and opportunities for the development of private HEIs since 1985. Consequently, resources in the private sector were actively mobilized which resulted in the rapid expansion of higher education in China. Later in 1993, the CCCCP reaffirmed its determination of education system reform and defined the decentralization on $\mathrm{HE}$ and reduction of government control over education institutes as a long-term policy (CCCCP, 1993). By means of legislation, fund allocation, long-term development planning and information services, the Chinese government has changed its role from micro-management to macro-management. The power decentralization on higher education of China allows local government to shoulder more administrative responsibilities on fund allocation and regulation. Meanwhile, non-public entities are encouraged to participate towards the development of higher education. As indicated by Mok and Lo (2007), non-public entities have consequently participated in the formal education sector which has resulted in the rapidgrowth of private higher education. Despite these changes in the past two decades, the supply of university or college graduates and hi-tech skilled labour cannot meet the demand of the economic growth caused by the reform and opening-up policies of China.

\section{RATIONALES FOR PRIVATIZATION IN CHINA}

Although privatization strategies have been widely adopted across the world, there is a debate on the drivers of higher education development strategy. Most of the theories supporting privatization consider the necessity of improving efficiency as the foremost justification for privatization. Taking public choice theory (Niskanen, William A., 1987) as an example, it can help to explain that governmental authorities tend to maximize budget rather than increase the efficiency of public services. Thus, to avoid this, part of the non-core services provided by government should be lessened by privatization (Hodge, 2000). Similarly, agency theory considers the public sector as an agent to provide services in accordance 
with contracts. Expenditures increase when the goal of the contractor conflicts with the scope of work in the contract. Consequently, cost for supervision will add cost to the total expense and privatization can be an alternative solution for cost saving (Eisenhardt, 1989). As far as efficiency and effectiveness is concerned, property right theory suggests that private ownership operates better than public ownership. (Mahoney, 2004). Particularly, it is indicated in human capital theory that expenditures on human capital are an investment rather than consumption. Due to the reason that such investment benefits individuals and society simultaneously, the cost is more reasonable to be shared by both private and public sectors (Becker, 1964; Blundell, Dearden, Meghir \& Sianesi, 1999; Goode, 1959). Hence, in order to privatize public education, the "user-pay" principle can be used; contingency theory states that privatization is more pragmatic, and its drivers are mostly contingent demands. To solve problems emerging in different contexts, different strategies should be employed accordingly (Bennett, 1997; Feigenbaum, Henig, \& Hamnett, 1998; Hodge, 2000). Bennett (Bennett, 1997) proposes a categorization that includes most of the usually stated objectives. By applying Bennett's categorization, this essay will analyze the major objectives of privatization in China.

\section{CRUCIAL ISSUES FOR PRIVATIZATION OF HIGHER EDUCATION} IN CHINA

Although the expansion of privatization in HE sector has brought benefits to China, it has caused problems also. Some of the major problems caused by privatization of $\mathrm{HE}$ will be discussed as follows:

\section{A. Quality assurance}

With the development of economic and marketization, higher education in China has developed at an unprecedented growth rate. Meanwhile, some people are worried about the quality of higher education that expanding at such a high growth rate. It is undeniable that the Chinese government has successfully achieved high-speed growth in its economy via the reform of marketization and the increasing connection with other global economy. According to Organization for Economic Cooperation and Development (OECD, 1998), the economic growth has generated an increase of both public and private expenditure on $\mathrm{HE}$, particularly when education is considered as kind of investment on human capital. It has been shown by the growth of enrolment rate at various levels in China (Ministry of Educating of the P.R.C. Network, 2016). Despite the growth in quantity, there have been concerns raised about the assurance of educational quality. The ratio of teachers to students is $1: 17.69$, indicating an insufficient supply of teachers catering for the increase in student enrolments. In China, many private education institutions tend to employ more part-time and retired faculty members which make it challenging to guarantee the quality of education. This is particularly true because there is not yet a well-developed quality assurance system of teaching in China (Chan, 2007).

\section{B. Stagnant internal management}

From the perspective of internal management, private HEI has deficiencies due to its own features. Generally, there are two types of management patterns adopted by private HEIs in China. The first one is the family-run management structure established based on the trust relationship between family members. In such case, most of crucial positions are taken by the chairman's relatives to ensure control of the HEI regarding its board, financing and personnel issues. Even more, after the chairman's retirement, the next generation will take over of institution. The other one is to invite famous persons to take up the post of emeritus leaders in order to attract the public attention and boost the institution's reputation and fame. Although corporate governance is set up in some of the private HEIs, still there are many problems regarding its internal management structure. Firstly, for most of the private HEIs, the board chairman holds a concurrent post of president, which results in power over-centralization. This happens to some private HEIs led by the communist party as well, in such HEIs, the secretary general holds two positions, the chairman and the president of board, at the same time. Secondly, due to the deficient organization of the board, in some private HEIs, boards are running without power of supervision both internally and externally. Even more, in some HEIs, there is no board member representing the institution staff. Thirdly, internal power is supposed to be appropriately separated among the board chairman, president and other board members, so is the functions for operating the institution. However, this is not the case for most of the private HEIs in China. For instance, when the chairman of the board misuses his authorized power, it is difficult and challenging for the president to exercise his supervision powers independently. Generally speaking, power over-centralized and power absences are common phenomena found in private HEIs of China. As a result, such management problems make private HEIs more vulnerable when they are dealing with risks.

\section{Lack of employability power}

The unprecedented speed of expansion in higher education generates large amount of job-seekers graduate from colleges and universities. Even though the economic has been growing at a relatively high speed, the increasing demand of employment is still far less than the increasing supply in the labor market. According to the research findings by Ministry of Education in 2015, only $91.7 \%$ of college or university graduates in China successfully find jobs within 6 months after graduation. In other words, 634.95 thousand graduates were unemployed for at least 6 months. In order to resolve the unemployed problem of college and university graduates, researchers have made efforts to find out the relationship between higher education expansion and graduate employment rate, wage levels in countries of different developmental stage. However, from previous literature, there is no clear pattern established to study these relationships. Additionally, the higher education expansion rate in China is uniquely high that historical expansion rates of higher education in other countries are incomparable. Still there are some findings in the report regarding the college and university graduates' employment. Firstly, it is easier for a 4-year graduate to get employed than a 2-year graduate does. Secondly, the employment rate varies 
among graduates of different majors; thirdly, for graduates from colleges and universities with higher ranks, the average employment rate is higher than those from colleges and universities with lower ranks. (Ministry of Education, 2015) Conversely, some of the advocates for higher education expansion argue that the supply amount of graduates is still far less than the actual demand and there are two causes lie behind the current tension of graduates' unemployment. On the one hand, most of the job opportunities are concentrated in the east, south and other developed areas or big cities in China. On the other hand, some graduates expect higher wages and more benefits than the job market can offer. It cannot be denied that some of the unemployment tension is caused by the mismatches between the labour supply and market needs. Whatever causes the unemployment for graduates, it has become one of the major problems for private HEIs expansion and its further development.

\section{RECOMMENDATIONS}

Considering all the critical issues faced confronted by private HEIs in China and from a sustainable and feasible point of view, some of the recommendations are suggested as follows:

\section{A. From a perspective of long-term development, an amiable environment should be established for the private HEIs in China.}

First of all, public awareness about the importance of developing private $\mathrm{HE}$ should be raised and some of the wrong understandings should be corrected. Generally, there are two types of wrong understandings of private HE. Firstly, some consider private $\mathrm{HE}$ as a supplementary form of public $\mathrm{HE}$ and the development of private $\mathrm{HE}$ is subject to public HE. To correct such kind of view, the public should be aware of the rationality and necessity of the existence private $\mathrm{HE}$ so as to create a fair environment for both public and private HEIs. Secondly, due to the shortage of educational resource in the past, ordinary people seldom had the opportunities to receive higher education in universities or colleges. Therefore, higher education had been considered as 'elite education'. However, with the development of economic in recent decades, higher education is now accessible to all ordinary people. And HEIs should be responsible for the universal education to improve the populace's cultivation and support the development of economic. At a macro-management level, the Chinese government should regulated HE with more scientifically and democratically which allows more space for the development of private HEIs and creates a fair environment for both public and private HEIs.

\section{B. From a marketing point of view, a marketing analysis at} various levels should be carried out for private HEIs in terms of its actual supply and demand, and the consumers' affordability.

From a perspective of supply and demand, two hypotheses will be assumed and tested based on the private HEIs supply and demand in China. Firstly, if the market is a sellers' market, the provision of higher education is in short in China. In other words, the private $\mathrm{HE}$ is in an uptrend and relatively underdeveloped compared to the private HE in developed western countries. Therefore, with the government's promotion and support only, it is difficult for China to transform into a country with sufficient HE provision. And resources in the private sector should be mobilized as much as possible to participate in the development HE. With necessary mobilized resources need for $\mathrm{HE}$, both the public and the private investors can benefit from the development of $\mathrm{HE}$. On the other hand, if the HE market is a buyers' market, the provision of HE in China will be over-supplied. Regardless of the massive demand of $\mathrm{HE}$ in China, some of the HEIs in China are not able to recruit sufficient students to support their expense. Conversely, the provision of high quality education is often insufficient to satisfy the market's demand. Thus, the buyers' market exists in the low quality HEIs only. From a consumer's perspective, if people choose to receive higher education in private HEIs, it means people are aware of the importance of $\mathrm{HE}$ and trust in the education quality of private HEIs. However, due to the misunderstanding that HEIs are less developed, people actually prefer public HEIs than private HEIs to receive education even they are in the same conditions. Even more, student dropout problems have brought bad reputations to private HEIs, which have resulted in public distrust. To summarize, the sellers' market and the buyers' market coexist in the HE market of China depending on the qualities of HEIs. Considering the affordability of consumer group, although there is large amount of bank deposit in China, the consumption level of ordinary people in China still keeps at a low level. As indicated by Sun (2005), the economic inequality in China is getting more and more serious nowadays with its $20 \%$ people holding $80 \%$ of the total deposit. That means, for most ordinary people in China, the affordability for HE, especially private HE with more expensive tuition fees, is not as high as the bank deposit amount indicates. Therefore, the demand for private HE is still inadequate in China. Thus, it is indicated by the above discussion that, in order to avoid the oversupply of low quality HE provision, private $\mathrm{HE}$ in China should be appropriately developed. To eliminate the public misunderstanding and distrust of private HEIs, the government should promote and support private HEIs with friendly policies and strengthen the macro-management of private HEIs. In doing so, the public and private HEIs may be able to provide more high quality education to meet the market's demand.

\section{The alert and emergency response system for macro- management issues should be set up to ensure the sustainable and healthy development of private HEIs.}

Firstly, when dealing with emergent accidents arising from bankrupt private HEIs or private HEIs facing the risk of financial stress, emergency response system should be established to protect the interests and legal rights of proprietors and students at a maximum level and minimize the negative effect caused by the bankruptcy of private HEIs. To ensure the system works properly, two aspects should be taken into consideration. Regarding the placement of students in the bankrupt private HEIs, the government should make proper arrangements and owners of such bankrupt private HEIs should jointly take up the responsibilities. And corresponding measures and policies should be carried out to help the students 
in such bankrupt private HEIs to continue their education. Regarding the asset liquidation of bankrupt HEIs, all related activities should be appropriately carried out to pay off all debts of bankrupt private HEIs first. And then, considering that some of the assets of private HEIs are part of the public welfare, the remaining the asset liquidation should be equitably distributed. Consequently, the remaining assets will not be totally possessed by private owners or public, these assets will be allotted proportionally according to the shares of public and private investors.

Secondly, it is necessary to establish an alert system through which private HEIs can be kept on the track of healthy development. In doing so, the regulatory authorities of higher education are supposed to carry out the work of supervision in aspects of teaching, management etc. Some of the recommendations are suggested as below: (1) improve the standards of the entry threshold for private higher education and strictly follow the approval procedures. Meanwhile, administrative authorities should reinforce the macromanagement for private higher education. (2) Relevant policies should be introduced to support the development of higher education so that private HEIs and public HEIs can coexist in a relatively fair environment. (3) Due to the reason that healthy finance status is essentially important for the operation of private HEIs, supervision on the financial status of private HEIs should be strengthened to prevent embezzlement of operating funds. (4) Regularly examine the qualification of student enrollment to ensure that private HEIs are qualified to set up programs and course and issue relevant certificates. (5) Operating information of private HEIs should be collected and analysis so as to establish a private HEIs alert system, through which regulatory authorities can identify existing problems of private HEIs and remind public of the risks. If necessary, regulatory authorities can even terminate the operation of private HEIs.

\section{CONCLUSION}

This paper has illustrated that the growth of privatization in the Chinese HE sector and analyzes some of the rationales that have been driven the growth of privations, but also indicates crucial issues and the demonstrates recommendations for the issues in higher education in China. The privatized higher education in China has been significantly growth, indicating their goal is for resource mobilization and the improvement of efficiency. On the side of policy, although certain autonomy being granted for typical functions of higher education universities/institutes in a free market economy, the state control of higher education is strict. Thus, privatization is more oriented to a reorganization of missions between the public and private HEIs than of control. As higher education system in China increasingly relies on private resources, probably fiscal stabilization could be an objective. In addition, as the inequalities cause by the market reforms and the privatization, social harmony has been promoted as a political slogan. Facing the widening education disparity associated with the growth of privatization, the government still encourage in the reforms and the privatization policies. However, it has found the possible problems and this paper gives the advice to tackle them.

\section{REFERENCES}

[1] Becker, G.S. (1964). Human capital: A theoretical and empirical analysis with special reference to education. New York: Columbia University Press.

[2] Bennett, A. (1997). The measurement of privatization and related issues. In A. Bennett (Ed.), How does privatization work?: Essays on privatization in honour of Professor V.V. Ramanadham (pp. 1-23) London: Routledge.

[3] Blundell, R., Dearden, L., Meghir, C., \& Sianesi, B. (1999). Human capital investment: The returns from education and training to the individual, the firm and the economy. Fiscal Studies, 20(1), 1-23.

[4] Central Committee of the Chinese Communist Party (CCCCP) (1985) The Decision of the Central Committee of the Communist Party of China on the Reform of Educational Structure . Beijing: People's Press.

[5] Central Committee of Chinese Communist Party, \& State Council. (1993). Zhongguo jiaoyu gaige he fazhan gangyao [Mission outline of the reform and development of China's education]. Beijing: Author.

[6] Chan, D. (2007) The Impact of Globalization on the Educational Developments in China: policy and challenges, in J.Y.S. Cheng (Ed.) Challenges and Policy Programmes of China's New Leadership . Hong Kong: City University of Hong Kong Press.

[7] Chou, C.P. (2008). Taiwan higher education at the crossroads: Its implications for China. Journal of Asian Public Policy, 1(2), 148-163.

[8] Eisenhardt, K.M. (1989). Agency theory: An assessment and review. Academy of Management Review, 14(1), 57-74.

[9] Feigenbaum, H., Henig, J., \& Hamnett, C. (1998). Shrinking the state: The political underpinnings of privatization. Cambridge: Cambridge University Press.

[10] Goode, R.B. (1959). Adding to the stock of physical and human capital. The American Economic Review, 49(2), 147-155.

[11] Hodge, G.A. (2000). Privatization: An interview review of performance. Oxford: Westview Press. Eisenhardt,

[12] Huang, F.T. (2005) Qualitative Enhancement and Quantitative Growth: changes and trends of China's higher education, Higher Education Policy, 18, 117-130. http://dx.doi.org/10.1057/palgrave.hep.8300076

[13] Mahoney, J.T. (2004). Economic foundations of strategy. London: SAGE.

[14] Ministry of Education of People’s Republic of China, (2016), Report of Chinese Educational Development Statistics of 2005. Retrieved on March. 26, 2017, from http://www.moe.edu.cn/

[15] Mok, K.H., \& Lo, Y.W. (2007). The impacts of neo-liberalism on China's higher education. Journal for Critical Education Policy Studies, 5(1).Retrievedfromhttp://www.jceps.com/index.php?pageID.article\&arti cleID.93

[16] Niskanen, William A. (1987). "Bureaucracy." In Charles K. Rowley, ed. Democracy and Public Choice. oxford: Basil Blackwell.

[17] Organisation for Economic Cooperation and Development (OECD) (1998) Human Capital Investment: an international comparison. Paris: Centre for Education Research and Innovation, Organisation for Economic Cooperation and Development.

[18] Shi, Q.H., Wu, M., You, S. \& Liu, W. (2005) Affiliated Colleges and Private Education Development in China: take independent colleges as an example.http://www.ocair.org/files/presentations/Paper2003_04/forum2 004/ChinaHE.pdf 